\title{
Thala in the Kabyle village: feminine drudgery or social link
}

\author{
B. Belmessaoud-Boukhalfa \\ Polytechnic School of Architecture and Urban Planning of Algiers, \\ Algeria
}

\begin{abstract}
Values as humility, democracy, solidarity, equity or individual freedom are common in traditional societies, the difference lies in the prevalence of a value over another, on one hand and by the appreciation related to the object in question on the other hand, which depended on the organization of the considered society and its convictions. Thus, any culture, any society has in connection with these concepts a clear and structured vision as much by its history as by its convictions. It has a clear and structured vision according to its history as its relations with the other and its own values. Today, ambiguity and blur characterize our vision of values because reality is alienated and reduced to its mere material dimension. The moral dimension of human life, including contemporary perplexities which rise from research to apply ethical principles, in situations without precedent, presents challenges for societies in their search of good decisions and right procedures. Ambiguity between traditional values and modern values leaves society confused. The example of individual freedom seems to be the most discussed value, in particular concerning the feminine subject. This article introduces the issue with the analysis of the feminine duty of water into the Kabyle village. It sheds light on the disappearance of the public place devoted to women that emerged with modernity. In the first part, it gives an outline of the organization of the Kabyle traditional society and its village. In the second part, it exposes the significance of the source of water and the issue of the polemic considering it as drudgery, relating to the feminine condition or as a social link suitable to be preserved. In conclusion, the article questions the fate of this source in contemporary Kabyle society.
\end{abstract}

Keywords: $\quad$ source of water, Thala, Kabyle Village, Kabylia, Kabyle woman, feminine duty of water, traditional society, significance of the source of water. 


\section{Introduction}

Contrary to Morocco where the European city was built beside Medina, the colonial cities in Algeria took the place of the old cities to the detriment of the old cores where boulevards were pierced and many constructions demolished. After the independence, the undertaken model of development hardly changed attitude concerning the urbanization. As Etienne [1, p. 32] underlines, there was a distortion whose key was the ethnophobia. The leading class used European urban space but suggested an ethno-centrist model. Nevertheless, this vision is far from being real because the advent of the socialist village as an example thought like social project and endowed with a mental representation with a new system of values - will accentuate the phenomenon of acculturation undertaken by colonialism. This fact succeeded in compromising the mental image of the peasant and confused its traditional system of values. Massive industrialization and schooling will devastate the urban Algerian landscape and destroy the structure of the traditional family and society. After the liberation of the country, the Algerian campaigns had as heritage only total destruction. Those are as many imbalances which had as a consequence a massive exodus of the rural populations towards cities. Thus neglected, the mountain villages of Kabylia in particular, disappear ones after the others at a frightening rhythm. They are not subject of any preserving measure or protection, except, the traditional village of Aït el Kaïd in Tizi-Ouzou Ministère de la Culture [2]. The socio-economic changes and the unrestrained city planning of these last years accentuated more the degradation of the majority of the villages.

Medieval Cities and last witness of a way of life and local skilfulness in settlement and architecture, they reflect the cultural values of the Algerian society to preserve just like the Kasbah of Algiers or Ksours of Timimoun which were classified [2]. Moreover, as Lacoste-Dujardin [3, p. 119] underlines it, Algerian Kabyles aspire to be inspired by their cultural values and the traditional mountain structures and thus think of reviving them. Also, it is high time to bring together all the dispersed pieces of the culture of the Algerian heritage in order to build a durable future to the country.

\section{Kabylia}

When the toponymy of Kabylia is evoked, it is wise to question about the use of the word. It comes from the Arabic word qaba' $\hat{\imath} l$ which was not employed in the sense of a regional specification. The area aroused much of the French colonist's interest, and until the end of the 19th century, the Berber-speaking populations were still known under the name of Kabyles (Jucovy and Alderete [4]). The traces of the human activity in Kabylia go back to the prehistory, as attested by its many archaeological discoveries such as lithic industry, engravings and the cavern paintings (Adli [5]). The first contacts with the external world go back to the Phoenicians (Carthaginian) but the mountains remained inaccessible to the various intrusions until the arrival of the French who succeed to occupy the mountains for the first time of the history in 1857 (Ahmad Zayed [6]). The 
French resorted to "the burned earth policy to oblige those villages and tribes who were not subdued by fight, to capitulation." But they could not destroy the Kabyles' values (Boulifa [7]).

Concerning the Kabyle civilization Remond [8] was suspicious by considering it quite poor... without any feeling of a higher nature able to group and link. However, the Amazighs in North Africa practised the art of building and created a type of original and thousand-year old habitat in clay and stone according to ancestral techniques which are the Kasbahs, the collective attics (ighreman) the tazota-s, the ksour-s and fortresses. Often, the city was preceded by a Berber agglomeration, as attested by the toponymy (Tighramt and Ighram). Kabylia is divided in detached houses or hamlets (tikharubin) and into villages from more or less important size (tudrin) (Aït Larba [9]). The concerns of defence, the harsh climate (Braudel [10]) and also a certain instinct of race led Kabyles to be established on the crests. They see the slopes and cultivate the cultivable lands but they do not have water so it was necessary to go for it to the source situated at a long distance and it was the principal and daily labour women.

\subsection{Organisation of the traditional Kabyle society}

Few historical details are available concerning the origins of the Kabyles. At primeval age the Berber tribes were attached to the Arab nation via legendary ancestors (Ibn Khaldoun [11]). Three filiations are advanced: the first, the most frequent, proclaims the Berber originating from Palestine, driven out in the Maghreb after the death of the prophet Jalut who belongs to the Arab tribe of Mudar. The second sees the Berber descendants of Cham, Noah's son, born (the Berbers) in the Maghreb after his exile. The third grants to several Berber tribes a himyarite and sudarabic origin. Kabyles are very conscious and proud of their so much strong identity founded on their quality of imazighen ("free men") and also on the quality of imesdurar (mountain) never colonized. The maintaining in Kabylia of a laic social system, single in Islam, was possible thanks to the Moslem religious (marabouts) who confined themselves in an exclusive clerical role. While preserving the isolation of their families, sheltered in their villages, the men often move outside Kabylia, in all Maghreb and even out of borders (in France), but without modifying their fundamental internal structures, to which they mark a ferocious attachment. To save land and anxious about their defense, they built their dwellings on unsuitable cols, hills and narrow gorges unsuitable for any culture, back to the sea because the sea's image for them is synonymous of suffering, destruction and death. They kept the slopes for cemeteries and the grounds with low relief to agriculture. Practically, all villages are similar to each other in their structures and their geographical situations. The social structures are dominated by a tendency to a 'self-defense' and to a fraternal solidarity, which appears even in all the ways of life. The Kabyles prefer the marriage "within the family" (paternal). Thus, all the inheritance in goods, moral values and honor is ensured to remain within the patriarchal family without risk. In the same way, the possessions remain as much as possible in combined possession in the same paternal family that prevails in this patriarchal system and condemns 
any individualistic failure to this rule. So that the resources, the goods and the richness and especially the symbolic capital (Kabyle honor) are jealously safeguarded within the group of relationship in which each one is enrolled. The land is the source of subsistence and honour. It is the patriarchal organization in all its simplicity; neither caïd, nor sheikh but simply Thajmaât or djemaa's (Delartigue [12]). Kabylie is organized in 'arches (plur. 'rouch). The ârch was traditional social and political structures formerly widespread in the whole of pre-colonial Algeria, and gathered a certain number of villages. Thaddart or thamourth is only used in Kabylia to indicate the village or dechra (pl. dchour) in Arabic.

The village was, one century ago, an administrative and political unit which enjoyed autonomy comparable to the "village republics". An assembly (thajmaat) managed it: it was made of all the pubescent male citizens, it made the laws enacted by old respected veterans, repealed those which were not appropriate and enacted some new laws according to needs. It is still thajmaât which decided free and obligatory community work (twiza), collected the tax, declared war and managed the goods of mortmain (awqafs or habous). Thajmaât elected a chief of the executive who chaired the assembly and applied its decisions, according to the regions, lamin, n'thaddart, amuqran, etc... The chief or the chair of the assembly was assisted by an assistant, called tamen or oukil. By preoccupation of democracy and pluralism, one generally chose it in the hostile party (çaff) with that of the chief. It was a means of controlling the lamin maneuverings and of denouncing any abuse of authority and any excess (Aït Larba [9]). Kabyle society is composed by a series of 'encased' communities, presenting concentric circles of fidelity which have their name, their goods and their honor" (Bourdieu [13]). The village consists of consanguineous family groups called taxarubt (fraction), and around it were grouped other foreign families to form adrum (district). There can be two or several districts in a village and a certain number of villages form the ârch (tribe) and then taqbilt (a tribe's confederation necessary to face an invader). By increasing order of magnitude, we obtain: axxam-taxarubt-adrum-taddart-aârch-taqbilt (Lasheb [14]).

This agrarian society was based on the man power to work the land, but also on ancestral laws (pre-Islamic) of the heritage. It was based on the man/woman complementarities expressed in the agricultural work: for example, the man climbs on the olive-tree, cuts it while sapling olives; the woman, during this time, collects olives. She gives birth to children and educates them, executes the domestic duties, brings back water from the fountain or source, takes part in the agricultural work compatible with her physical force, weaves the carpets, produces pottery etc... On the other hand, women are exempted from some practises as to attend meetings of thajmaât, to go to the souk, to travel on her own ... etc. In reality, this fact is due in one hand, to the social organization of the work based on the physical force of the male which is essential, and to the values of the horma (the respect) of the society on the other hand (because woman is invested of purity inside domestic space, by going out in mixed places she can be subject to impurity and hurt of the honour). Furthermore a cultural 
distinctiveness - the quasi sacred character of the land, of the roots and ancestors- is that the sale of a parcel of land in its village is regarded as forfeiture for the Kabyle. Thus woman does not inherit. However, if she does not inherit in the traditional society, the woman had a privileged statute because her father, her brother or her husband, were responsible for her material comfort but also to preserve her honour. Thus, the custom envisaged two solutions to the problem of their subsistence: right of protection of maintenance on the incomes of the succession and the assignment of one part of the succession buildings by the attribution of usufruct (Gahlouz [15]). Another character of this traditional society is the la'naya (protection) which softens these severe campaign morals. It extends a network of reciprocal benefits to all the Kabyles. The security offered to whom possesses the la'naya is beyond the rights given to a citizen by the guardianship of ordinary law. Woman enjoys even more of this privilege.

\subsection{The Kabyle village}

When the French arrived to the Maghreb and initially to Algeria, they found a society much diversified but which has a secular reference to Arab-Islamism. The whole social organization produces a type of city which is a centre revolving around the three basic activities: the mosque and its appendices, the medersa and a zaouia of brotherhoods where are exerted cultural activities and cult (Etienne [1, p. 33]). However, in our sense, this description corresponds much more to the Kabyle village organization (post-ottoman) which presents a number of common points with the Islamic city. Reflecting the agrarian mode, strong community cohesion, village space with its tightened structure is introverted on itself, hostile to the outsider and thus preserving the intimacy of the family and the group. Conceived without preconceived plan, the village is strongly integrated into the site with its topographic variations while fixing the shape of the fields and the arrangement of the habitat (Fig. 1). The villages are either of round or lengthened form. Just like in the Kasbah, the Kabyle village is traversed with a network of dead-ends and narrow alleys; some are cut in the rock and covered.

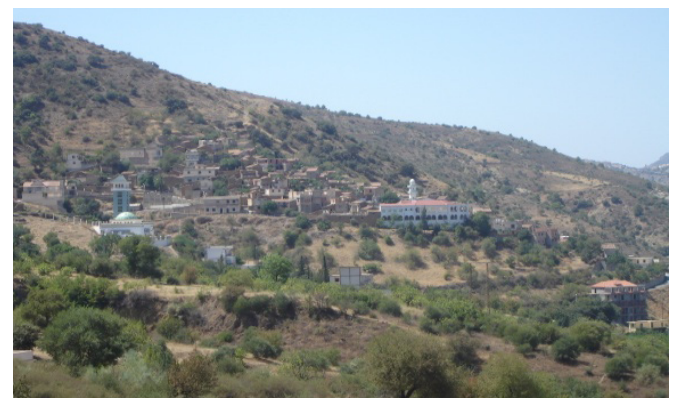

Figure 1: The historical village of Seddik Ouffela (near Beni-Warthilane) at Sétif (author). 
For reasons of safety and intimacy, the village opens to the outside only by two or three streets, and any foreigner penetrating there is immediately located. The Kabyle village roughly describes a circle around the top with a network of roadway systems generally crossed by one or two penetrating ways which allow to the foreigner which does not have business in the village to pass without entering there. The paths connecting the villages between them are for the great majority crest paths and produce a surprising structure of the territory. The villagers could thus ensure their safety and the control of the fields and intervillager spaces. Kabyle village has the thajmaât place, a zaouïa, a qoraba, a rural market or souk and a source of water or Thala which its situation differs from a village to another but frequently distant. The houses are disposed by files and are joined by their gables pinions, according to the divergent radius of their top, as much as the irregular shape of the ground allows it. The alleys and the courtyards separate the rows of the houses. Summarily, the typical plan of a village is a circle whose juxtaposed buildings would materialize the radius with a profile in terraces where each house overhangs that which follows it. The built villages merge with the land. The new houses take again the layout of the old ones; sometimes one arranges a little the interior, but, without gaining on the alley, or leaving to the latter more width. One builds as the family increases. The peripheral houses joined together and split with loopholes ensure the role of ramparts. In fortified cities, the access to these villages remained meticulously controlled. It was not usual that a traveller, Kabyle or foreigner (averrani) cross the village. If this one could not justify his passage, he has to get the ways of contours, always downwards. Thus, the safety and the intimate character of the village remained preserved. Thajmaât (or Djemâa according to the Arabic term), at the village entrance and where is held the public assembly, filters the access to the village. These obligatory passages in the Kabyle villages are different from the simple roofed passageway-furnished with benches- to an agora. These rustic agoras were used as doors to the village. The old men and the jobless spent most of their time there, sitting to palaver and to ensure a vigilant and inexpensive guard. The zaouïa is composed of a mosque, of a place where only the Quran is read, of a place reserved for studying sciences, of a place used as primary school for children, of a residence intended to pupils and to tolbas who come to make or improve their studies; and finally, of another dwelling where one receives the beggars and the travellers. The zaouïa is a religious university and a free inn (Daumas and Fabar [16]). The zaouaïas are an object of particular veneration for people. Even converted to Islam which found an echo in their heart, the Kabyles could not remove a part of their beliefs and habits, even stronger than the religion, such as the zerda, a celebration during which all the inhabitants of the neighbourhood villages meet and where oxen and sheep are butchered. In their profound humility, there is a need to intercede the saints in their favour to Allah but not the remains of paganism. In practice, these celebrations are events of major solidarity and equity, where all poor receive their share of meat (Thimechret or wizi'a), in addition to the fact that all the women cook together, and where everyone feast convivially. For Raymond [19], the associative phenomenon is deeply anchored in the Maghrebian urban culture and was at the 
base of the administration and the management of the traditional cities of the Moslem world. The qoraba or thakorabt (in Kabyle) is mainly the tomb of a saint, patron of the village surmounted of a koubba or dome (Oukil [17]). With its Quranic schools, it was especially a place of sharing knowledge, and teaching of Islamic sciences, and its great sheikhs were trained in these schools (the son of Al Ghubrînî was a mufti at Tunis, Abu Ar-Rûh Al Menguellâtî cadi at Gabès etc... (Lalmi [18])). However it should be noted that in certain villages, the qoraba is external to the mosque. There is no confusion between the medersa and the qoraba; the education took place in the mosque. The rural market or souk is the structure ensuring the public life in traditional social space outside the village which is parcelled out and decentralized in strongly constructed confederations and clans. Côte [20] defines it and locates it as decentred within a community territory, near the neighbouring territories. Justice could be passed there by the cadi who is the local representative of justice.

\section{The source of water Thala}

As in thajmaât and the souk for men, Thala is the place for the women of the village and is devoted to many practices. Such traditions and practices produce an image of this society without writings; in this case, the tale is the fundamental element of expression of some of its structural characters. Such characters appear through a set of signs. The sign is representative of something else that reminds as a substitute. Anything can be a sign as long as someone interprets it as 'signifying' something -referring to or standing for something other than itself. Signs take the form of different objects, but such things have not any meaning and become signs only when we invest them with meaning. Meaning includes denotation and connotation. Most signs have at least one normal, "common sense" meaning. This meaning, called the sign's denotation, is shared among many people and is the most widely used meaning of the sign while the connotations of the sign emerge from each individual's personal experiences. So, the denotation of a sign represents an agreement among a group of people that they will share that meaning of the sign among themselves. Meanings of this type arise through social convention. Signs are generated also by myths and in turn serve to maintain them. In this way, tales are the elementary field of investigation and a tool of perpetuation. We endeavor to find the meaning through tales which can represent those traditional practices.

\subsection{Ancestral practices in Thala}

According to ancestral customs' whose exercise is considerably reduced lately, Thala is the crucible of social practices that mystical connotation allotted to it the statute of holy place just like the cemetery or the mosque of the village. In Thala, women of the village get information, tell all kinds of news on harvest, marriages in sight, marital disagreements, and envisaged births. But, for our villagers, to go to the fountain has another goal, especially in summer period where festivals take place. When the opportunities of the religious feasts arise, Thala is visited 
as well as other sacred places where one implores the Most Powerful [Allah] with offerings and chants. A few days before and after the celebration of a marriage, the new bride should make a visit to Thala of the village to put down a waâda (a gift) so that the marriage takes place under the best conditions as possible, and the second time she should fill there a small pottery (jar) filled with beans as a sign of fertility. The empty jug in the house constituted safety for the fair sex since it was the only admissible alibi which enabled her to extirpate herself from house stress and to allow herself a few moments of escape. But, these villagers paid their relative freedom harshly because bringing back water from Thala, often located outside the village, was a true hard work especially in bad weather. At determined hours, the women called each other at their passage to the source (Fig. 2). They get there their laundry done, they went there to separate oil from the already triturated paste, to press oil. The distance of the sources, served by rising and difficult paths, was to remove much charm to the daily water chore. The places, like the streets, the fountains, and the ways were subject of fines inflicted for the pollution of the fountains, the jet of waste in the inappropriate places and good citizenship necessary to the community life. Thus, paths were traced to go to the fountain. Everything was done to avoid the meetings between men and women in particular on the paths or in the fountain and so to impose a bisexual and/or alternate spatial occupation; because men accomplish their ablutions there (wudhu or washing before prayers) early in the morning.

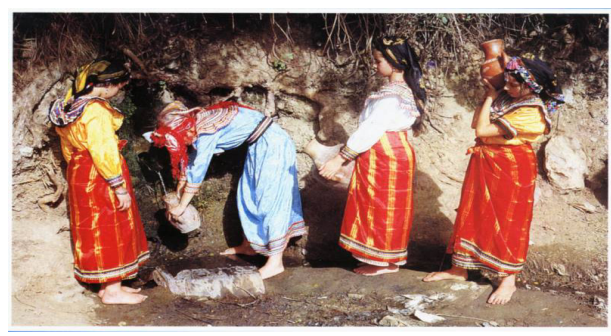

Figure 2: Thala, the feminine meeting privileged place (www.gelambre. pagesperso-orange.fr).

\subsection{Symbolic and significance}

Fountain and water have great part in the Kabyle tale. In traditional Kabyle folk tales, water is one of the objects in search of, which the valorous hero must go to query at the peril of his life, water which emerges from anfractuosities, magic water, source of life and youth, and miracle cure (Lacoste-Dujardin [3, p. 123]). According to the study of Ouamara [21], hydromancy flourished amongst Kabyles and Berbers in general. Rivers and sources are places of a worship addressed to deaths. Their presence gives to water its fertility, its capacity of regeneration and rebirth. The symbolism of water is then regeneration. In Berber country, it is a remedy for the degeneration of any form of life. The fountain is 
frequently the place where the enigma between the hero and the setut (witch) began. It is there that all the future action is preceded and all kinds of metamorphoses are realized. Regeneration is a serious and dramatic act which could not be achieved without social disorder. The social activities wear out and should be regenerated. The disorder which characterizes the trial of regeneration leans on the inversion of the roles of all kinds while revealing the oppositions crowned /profane, masculine/female, culture/natural, inside/outside, dryness/wet. In the Kabyle tale, there would be implicitly an idea of a cosmos and human collective regeneration. The tales goals are often activated on the sterility of the woman and, correlatively, of the family, even of the danger of the nonreproduction of the society. Regeneration is, as its name indicates it, a new birth. The recovery of order is made by the offering to 'invisibles'. In short, it is the renewal of the social group. Water is also a type of destiny, an essential destiny which unceasingly metamorphoses the being's substance (Bachelard [22]). The fountain's brink is regarded as a point of convergence of the worlds (ClaudotHawad [23]). The results are summarised in Table 1. The negative points are listed in order to find the main practical problem to the preservation of Thala.

Table 1: The symbolic value of the source, its principal activities and negative points.

\begin{tabular}{|c|c|c|}
\hline Symbolism & Activities & Negative Points \\
\hline Source of life & Moment of freedom & $\begin{array}{l}\text { Situation in outside } \\
\text { of the village }\end{array}$ \\
\hline Source of youth & Moments of escape & $\begin{array}{l}\text { Accessibility with } \\
\text { rising and difficult } \\
\text { paths }\end{array}$ \\
\hline $\begin{array}{l}\text { Miracle cure for the } \\
\text { degeneration }\end{array}$ & $\begin{array}{l}\text { Place of meeting and information } \\
\text { exchange }\end{array}$ & \\
\hline Fertility & $\begin{array}{l}\text { Visit: filling of a small earthenware jar } \\
\text { filled beforehand with broad beans as a } \\
\text { sign of fertility }\end{array}$ & \\
\hline $\begin{array}{l}\text { Power of renaissance and } \\
\text { regeneration; offering to } \\
\text { 'invisibles' }\end{array}$ & $\begin{array}{l}\text { Imploration of God (offerings, chants) } \\
\text { Visit of the bride and deposit of a } \\
\text { waâda (gift) }\end{array}$ & \\
\hline $\begin{array}{l}\text { Oppositions sacred/profane, } \\
\text { masculine/feminine, } \\
\text { culture/natural, inside/outside, } \\
\text { dryness/wet }\end{array}$ & $\begin{array}{l}\text { Bisexual and/or alternate spatial } \\
\text { occupation }\end{array}$ & \\
\hline Recovery of order & & \\
\hline $\begin{array}{l}\text { Statute of holy place like } \\
\text { (cemetery or mosque ) }\end{array}$ & $\begin{array}{l}\text { Mystical connotation of social } \\
\text { practices }\end{array}$ & \\
\hline $\begin{array}{l}\text { Point of the worlds } \\
\text { convergence (brink or edge) }\end{array}$ & $\begin{array}{l}\text { Separation of oil from the triturated } \\
\text { paste of olives } \\
\text { Laundry of the house } \\
\text { Meeting and information exchange }\end{array}$ & \\
\hline
\end{tabular}

\subsection{The issue of the polemic}

The polemic concerns the women's liberation from the domestic harsh conditions. The introduction of the tap occurs with modern comfort and releases 
the woman of this task. Tackled in a way as much sociological as ethnological, the topic of the condition of the women always caused many work and debates. One of the first thoughts likely to occur within the framework of any historical reflexion on feminism is that it is a typically modern movement. But, beyond the fact of this modern release and its comfort, the contemporary woman is totally excluded from the public place; and except in the workspaces, she is paradoxically relegated more than ever before to domestic duties, without a place of meeting with her pairs. For certain villages, the fountain -from its privileged place in the middle of the city centre and which was useful before as women place of conviviality- becomes a place of meeting and regrouping for young people. The 'modern' conditions are those created by technological progress as stressed by Lovibond [24]. They are the kind of conditions which rout out people coming from old communities and force them to negotiate their own survival in a capitalist 'free' market. The classical "centred subject" was free because he was not any more at the mercy of the unpredictable assaults of his different appetites; by analogy, the modern subject is free under the terms of his release of the influence of the social forces which he does not understand any more. While the existence of the social and even the spatial structures of the community are thus questioned by this freedom. The current society is torn between two ways of life: the incomprehension of the precepts of Islam which govern the social relations, the traditional values of which it is profoundly impregnated and modernity with its contradictory values. A must, the public space conceived in the spirit of Western modernity could not be adapted and fully lived by contemporary women, at least at this moment. The society is too impregnated with ancestral values - existing well before Islam. As Gahlouz specifies [15] by their sexual integrity which must be preserved and by the value attached to their purity, the women are enveloped with a sacred character which is expressed through the concept of haram (prohibited),... translated by particularly severe requirements in the qanun-s (laws) set up with a founder principle: the defence of the honour.

Attempts to reconcile modernity and traditions emerge -that remain to be evaluated- and are concretized in new spaces devoted to women in respect of social customs and habits. A shopping centre reserved to women is a case of a public space released from the social control and dedicated to consumption. The woman's Realm is the reserved floor to women at the shopping centre ( $\mathrm{Al}$ mamlaka) in the "glamour" new city centre of Riyadh, since 2001 (Sassen [25]). The lady floor is a "space of freedom and intimacy" (khusûsiyya or privacy) for the Saudi ladies in the respect of the "habits and traditions" of the society. With its shops, its coffees and its restaurants, this closed and safety place is emblematic of the conditions under which the access of a certain category of women to public spaces is developed, in a paradigmatic city of the segregation of kind since the years 1980 (Le Renard [26]). The transformation in the respect of the habits, of Islam and the specificities of the traditional society predicts maybe a certain reconquest of public spaces by women which remains to be developed beyond consumption to other activities which could allow to women a real participation in the development of the country. 


\section{Conclusion}

Today, the Kabyle village-in total typological rupture with the former modelchallenges us. Dismantled even more by terrorisms of the nineties, these villages are in state of disrepair while being emptied of their population. Their traditions are not any more practised only through a restricted number of villages. However, Thala as the village is a source of regeneration for the Kabyle society, where the individual feel renewed or revitalized even after the exile. It remains an important place of ancestral practices and in extreme cases of the mythical one. Consequently, the rehabilitation of fountains exceeds by far the economic need to circumvent a mere drinking-water scarcity situation. It takes part in the restitution and the regeneration of a piece of our ancestral patrimony which should make the younger generations pride -in prey with terrible overlapping of multiple civilisationnels reference. If some practises which are not orthodox (zerda) are considered as paganism, which new practices can substitute these moments of meeting so privileged for the populations? Much more than the arising problem of the source of water, a crucial question emerges concerning the disappearance of women from the Algerian public space, more especially these convivial meetings so much important for solidarity and exchange within the society. Does the source find again- beyond its inaccessibility- its role, as the system of Thajmaât which seems to have recovered dynamism? An urgency is to create spatial structures likely to regenerate the interdependent movements of ancient times, to extend the restricted cohesion of Thajmaât - exceeding the specifically Kabyle claims. A certain aptitude towards an aspiration to a national scale creates a durable and coherent organization of the Algerian society.

The traditional tales also, affirm their importance because they maintain traditional modes of communication of the social structural characters that increasingly disappear and allow the development of the imaginary of a child. Or as resumed by Fisher [27], the industrial world logic will remember from minority communities only folkloric and sweeten relics.

\section{References}

[1] Etienne B., Le Flou urbain: L'Affrontement des Modèles, Annuaire de l'Afrique, XI, 1972

[2] Ministère de la Culture, Schéma Directeur des Zones Archéologiques et Historiques; (éd.) Direction de la Restauration et de la Conservation du Patrimoine Culturel, 2007

[3] Lacoste-Dujardin C., Grande Kabylie: du danger des traditions montagnardes, Hérodote, 2002

[4] Jucovy K. \& Alderete J. (2001) in www.swarthmore.edu

[5] Adli Y., La Kabylie à l'épreuve des invasions, Editions Zyriabes Algérie, 2004

[6] Ahmad Zayed M., Toponymie villageoise Kabyle. Tiziri ${ }^{\circ}{ }^{\circ}$, Belgique, 1999 
[7] Boulifa S. A., Le Djurdjura à travers l'histoire, Bringau, Alger, 1925, rééd. Berti, Alger, s.d. p.2-3

[8] Remond M., Au cœur du pays kabyle. La Kabylie touristique illustrée des années trente, rééd. Publisud, Paris, 2001

[9] Aït Larba S. : Vieilles cités de Kabylie. La Dépêche de Kabylie 31/10/2007

[10] Braudel F., La Méditerranée, l'espace et l'histoire, Flammarion, Paris, 1985, p. 27.

[11] Ibn Khaldoun, Histoire des Berbères et des dynasties musulmanes de l'Afrique septentrionale, traduit par De Slane, rééd. sous la direction de P. Casanova, Paris, Paul Geuthner, 1978, 4 vol.

[12] Delartigue Lt. Colonel du $3^{\circ}$ Zouave, Monographie de L'Aurès : Documents sur Batna et sa Région. Constantine, 1904

[13] Bourdieu P., Sociologie de l'Algérie, PUF (Coll. Que sais-je ?), Paris, p.12, 1970

[14] Lasheb R., Toponymie village kabyle Patrimoine - Noms des lieux habités de Kabylie (noms composés); La Dépêche de Kabylie du 17 juin 2009

[15] Gahlouz M., Droit coutumier et régulation dans la société kabyle de la fin du XIXe siècle, Droit et cultures, http://droitcultures.revues.org/2359

[16] Daumas M., Fabar M, La Grande Kabylie Etudes Historiques, Hachette et Cie Librairies de l'Université Royale de France Paris ; 1847

[17] Oukil E., Histoire de Takorabt N'Ath Abbas in www.takorabt.com

[18] Lalmi N. A. Du mythe de l'isolat kabyle études et essais. Cahiers d'études africaines. http://etudesafricaines.revues.org/4710

[19] Raymond A., Les zones de résidence dans les grandes villes arabes à l'époque ottomane, Actes du symposium international d'études ottomanes, Centre d'études et de recherches ottomanes, Zaghouan, pp.185-193, 1994

[20] Côte M., L'Algérie ou l'espace retourné, Media-Plus Algérie, 1993, p. 80

[21] Ouamara A., La Régénération dans le conte Kabyle, Études et Documents Berbères Périodique $\mathrm{N}^{\circ}$ 14, 1996, pp.143-152

[22] Bachelard G., L'eau et les rêves, José Corti, 1942, p. 8; 77

[23] Claudot-Hawad H., Touaregs: L'Identité en marche. Études et Documents Berbères, 14, pp. 223-232, 1996

[24] Lovibond S., Feminism and Postmodernism, (unknown), pp. 9-10

[25] Sassen S., Whose city is it? Globalization and the Formation of New Claims, Public Culture, Vol. 8, n², pp. 205-223., 1996

[26] Le Renard, A., Pratiques du shopping-mall par les jeunes Saoudiennes. Sociabilité et consumérisme à Riyad, in Peraldi, Michel et Mermier, Franck (dir.): Karthala, pp. 187-214, 2010

[27] Fisher A., Fastueuse Afrique, Ed. du Chêne, Paris, 1984 